\title{
Morpho-functional characterization of equine endometrial epithelial cells in vitro - preliminary results
}

\author{
Denny Böttcher', Tobias Theuß', Alexander Kappe ${ }^{7}$, Axel Sobiraj $^{2}$, Heinz-Adolf Schoon $^{7}$ and Christin Ellenberger ${ }^{1}$ \\ Institute of Pathology ${ }^{1}$ and Large Animal Clinic for Theriogenology and Ambulatory Services², University of Leipzig, Leipzig, Germany
}

\begin{abstract}
Summary
Influences of different culture media and growth surfaces on morpho-functional characteristics of equine endometrial epithelial cells (EEC) in vitro were investigated in order to optimize culture conditions. Therefore, the results were compared to the endometrium in situ. Equine EEC were cultured using different media with varying serum components and additives: foetal bovine serum plus additives (MFBS+A), foetal bovine serum (MFBS), horse serum 1 (MHS1), horse serum 2 (MHS2) and horse serum 3 (MHS3). Uncovered and Matrige ${ }^{\mathrm{TM}}$-covered cell culture inserts, as well as cell culture flasks were used. Cultured cells were examined cytomorphologically (haemalaun-eosin staining, giemsa staining), cytochemically (alcian blue staining) and immunocytochemically (oestrogen receptor (ER) $\alpha$, progesterone receptor, proliferating cell nuclear antigen, inhibin- $\alpha$, cytokeratin $8,18,19$, vimentin, $\alpha$-actin, desmin, transforming growth factor (TGF)- $\alpha,-\beta 1,-\beta 2$, $-\beta 3)$. Further, tissue samples of the uteri from which the cells were isolated were examined histopathologically (haemalaun-eosin staining), histochemically (alcian blue staining) and immunohistochemically, using the above-mentioned antibodies. Regardless of the used media and the state of the endometrial cycle at point of isolation, two morphologically different cell types and three growth patterns were found. None of these facts led to apparent differences concerning immunolabelling. Whereas growth surfaces, duration of culture and state of endometrial cycle at point of isolation did not cause any obvious influences on the immunolabelling of EEC in vitro concerning the utilized antibodies, the culture media did. Especially cells grown in MFBS +A exhibited characteristics comparable to uterine glandular epithelia in situ concerning cytokeratin 8, 18, 19, TGF- $\beta 1,-\beta 3$ and ER $\alpha$.
\end{abstract}

Keywords: immunohistochemistry, cell culture, endometrium, epithelial cells, horse

\section{Morphologisch-funktionelle Charakterisierung equiner endometrialer Epithelzellen in vitro - vorläufige Ergebnisse}

Im Rahmen der vorliegenden Studie sollten mögliche Einflüsse verschiedener Kulturmedien und Wachstumsoberflächen auf equine endometriale Epithelzellen (EEC) in vitro überprüft werden, um optimale Kulturbedingungen für diese Zellen zu schaffen. Dafür wurden die Untersuchungsergebnisse im Vergleich zum Endometrium in situ betrachtet. Die Kultivierung endometrialer Epithelzellen erfolgte unter Verwendung fünf verschiedener Kulturmedien ("Medium containing foetal bovine serum plus additives", MFBS+A, "Medium containing foetal bovine serum", MFBS, "Medium containing horse serum 1", MHS1, "Medium containing horse serum 2", MHS2, "Medium containing horse serum 3", MHS3), die sich hinsichtlich ihrer Serumkomponenten sowie ihrer Additive unterschieden. Die Zellen wurden auf unbeschichteten und auf mit Matrigel ${ }^{\mathrm{TM}}$ beschichteten Zellkultureinsätzen sowie in Zellkulturflaschen gezüchtet. Die in vitro gezüchteten Zellen wurden zyłomorphologisch (Hämalaun-Eosin (H.-E.)- und Giemsa-Färbung), zyłochemisch (Alzianblau-Färbung) und immunzyłologisch (Östrogenrezeptor (ER) $\alpha$, Progesteronrezeptor (PR), Proliferating cell nuclear antigen (PCNA), Inhibin- $\alpha$, Zytokeratin (CK) 8,18 und 19 , Vimentin, $\alpha$-Aktin, Desmin, Transforming growth factor (TGF)- $\alpha,-\beta 1,-\beta 2$ und - $\beta 3$ ) untersucht. Parallel dazu erfolgten an Gewebeproben der Uteri, aus denen die Epithelzellen isoliert worden waren, histopathologische (H.-E.-Färbung), histochemische (Alzianblau-Färbung) und immunhistologische Untersuchungen mittels der aufgeführten Antikörper. Unabhängig von den verwendeten Kulturmedien und der endometrialen Zyklusphase zum Zeitpunkt der Gewebeentnahme können in den Zellkultureinsätzen und den Zellpellets zwei morphologisch differente Epithelzelltypen und zusätzlich bei den auf Zellkultureinsätzen gewachsenen Epithelzellen drei verschiedene Wachstumsmuster unterschieden werden, was jedoch mit keinem objektiv erkennbaren Einfluss auf das Expressionsmuster der Epithelzellen hinsichtlich der verwendeten Antikörper einhergeht. Während die Wachstumsoberflächen, die Kulturdauer sowie der zum Zeitpunkt der Gewebeentnahme bestehende endo-metriale Zyklusstand keinen objektivierbaren Einfluss auf das Expressionsverhalten der Epithelzellen in vitro hinsichtlich der genutzten Antikörper erkennen lassen, führen die verwendeten Kulturmedien demgegenüber zu deutlichen Unterschieden im Expressionsverhalten der kultivierten Zellen. Dabei zeigen insbesondere die in MFBS+A kultivierten Zellen im Gegensatz zu den in den anderen Medien (MFBS, MHS1, MHS2, MHS3) gewachsenen Zellen ein dem glandulären Epithel des Uterus in situ vergleichbares Expressionsverhalten hinsichtlich CK 8, 18, 19, TGF- $\beta 1$ und - $\beta 3$ sowie ER $\alpha$.

Schlüsselwörter: Immunhistologie, Zellkultur, Endometrium, Epithelzellen, Pferd

\section{Introduction}

Experimental medical research using cell culture models represents an approved alternative method to animal experiments (Freshney 1990). Regarding endometrial tissue various authors described cell culture systems for both human (Saty- aswaroop et al. 1979, Mylonas et al. 2000b) and animal endometrial cells including mouse (Uchima et al. 1991), pig (Groothuis et al. 2002), sheep (Sheldrick et al. 1993) and cattle (Yamauchi et al. 2003). Up to now, in vitro culture of both endometrial epithelial cells (EEC) and endometrial stromal cells (ESC) of horses is only described by Watson et al. 
(1992) and Buschatz (2007). Brady et al. (1992, 1993), Burghardt et al. (1995) and Day et al. (1998) cultivated only equine EEC. All of these studies concerning the EEC generally describe primary cultures. Several authors report on problems with passaging epithelial cells from various species and tissues, for instance human endometrial epithelial cells (Matthews et al. 1992, Mylonas et al. 2003) or equine tracheal epithelial cells (Shibeshi et al. 2008). Our research group reported on a successful sub cultivation of EEC due to a gentle sub cultivation protocol and a modified culture medium (Theuß et al. 2010).

The aim of the present work was to investigate the influence of different cell culture media and growth surfaces on morphological and immunocytochemical characteristics of EEC in vitro. Based on these findings culture conditions leading to an immunolabelling similar to the one of endometrial glandular epithelium in situ should be determined.

\section{Material and methods}

Animals and gross examinations

Endometrial tissue was obtained from the uteri of slaughtered $(n=2)$ and euthanized $(n=1)$ mares as described by Theuß et al. (2010). Anamnestic data of the three mares are shown in table 1. Uterus and ovaries of each mare were examined macroscopically. The stage of the ovarian cycle was estima- ted on the basis of the development and regression of follicles and corpora lutea, as described by Arthur (1958), VanNiekerk et al. $(1973,1975)$ and Kenney et al. (1979).

Isolation, culture, sub cultivation and visualization

The isolation method described by Theuß et al. (2010) was performed. One fraction of the isolated equine EEC was cultured in the same manner as specified by Theuß et al. (2010) using culture flasks. The culture medium used by Theuß et al. (2010) will be called MFBS+A ('Medium containing foetal bovine serum plus additives') in this study. Further cell fractions were allowed to grow in four different media comprising either foetal bovine serum ('Medium containing foetal bovine serum', MFBS) or three different types of equine sera ('Medium containing horse serum 1', MHS1, 'Medium containing horse serum 2', MHS2, 'Medium containing horse serum $3^{\prime}$ ', MHS3). All other culture conditions including plating density, atmosphere and medium changing frequency comply with Theuß et al. (2010). Table 2 shows the results of serological examinations (Institute of Physiological Chemistry, University of Leipzig, Leipzig, Germany, Prof. Dr. Almuth Einspanier) of the applied sera regarding their hormone concentrations. The detailed composition of the five different media is summarized in table 3. All cell fractions in primary culture (PO) grew on Millicell ${ }^{\circledR}$ PCF cell culture inserts $(12 \mathrm{~mm}, 3.0 \mu \mathrm{m}$ filter pore size, Millipore, Bedford, USA) in MFBS, MHS1, MHS2 and MHS3. In addition, cells cultured in MFBS were grown on Millicell ${ }^{\circledR}$

Table 1 Data of mares used in this study

\begin{tabular}{lccc}
\hline & mare 1 & mare 2 & mare 3 \\
\hline years of age & 13 & adult* & 15 \\
clinical history & severe arthrosis of the forelegs & no data available & severe recurrent airway obstruction \\
manner of death & slaughter & slaughter & euthanasia \\
\hline * & &
\end{tabular}

* Precise age is unknown.

Table 2 Serum hormone concentrations of sera used in this study

\begin{tabular}{lcccc}
\hline & \multicolumn{2}{c}{ Foetal Bovine Serum Gold ${ }^{1}$} & $\begin{array}{c}\text { Horse Serum } \\
\text { commercially available }\end{array}$ & \multicolumn{2}{c}{ Horse serum $^{2}$} \\
& & day 2 of the ovarian cycle & day 12 of the ovarian cycle \\
\hline abbreviation & FBS & HS1 & HS2 & HS3 \\
estradiol $(\mathrm{pg} / \mathrm{ml})$ & 0.5 & 8 & 21 & 17 \\
progesterone $(\mathrm{ng} / \mathrm{ml})$ & MFBS, MFBS+A & 2.9 & 8.9 & 10.6 \\
serum used for assembly of & MHS 1 & MHS2 & MHS3 \\
\hline
\end{tabular}

PAA Laboratories, Cölbe, Germany; ${ }^{2}$ blood obtained from a clinically healthy, 9 year-old mare, Large Animal Clinic for Theriogenology and Ambulatory Services, University of Leipzig, Leipzig, Germany, Prof. Dr. Axel Sobiraj

Table 3 Composition of cell culture media used in this study

\begin{tabular}{|c|c|c|c|c|c|}
\hline & $\mathrm{MFBS}+\mathrm{A}$ & MFBS & MHS1 & MHS2 & MHS3 \\
\hline basic medium & $\begin{array}{l}\text { Dulbecco's modified Eagle's Medium (D } \\
\text { Ham's F-12 Medium ' (DMEM:Ham's F- } \\
1 \% \text { Antibiotic-Antimycotic Solution' } \\
0.275 \% \text { Amphotericin B }{ }^{1}\end{array}$ & $\begin{array}{l}\text { MEM) }{ }^{1} \\
12 \text { - ratio } 1: 1)\end{array}$ & & & \\
\hline additionally: & $\begin{array}{l}2.5 \% \text { FBS } \\
1 \% \text { ITS }^{1} \text { (insulin, transferrin, selenium) } \\
1 \% \mathrm{HEPES} B u f f e r^{1} \\
8 \mathrm{ng} / \mathrm{ml} \text { epidermal growth factor } \\
\quad \text { (human, E. coli) }^{2} \\
0.5 \mu \mathrm{g} / \mathrm{ml} \mathrm{hydrocortisone}^{3}\end{array}$ & $10 \%$ FBS & $10 \% \mathrm{HS} 1$ & $10 \%$ HS2 & $10 \% \mathrm{HS} 3$ \\
\hline
\end{tabular}

1 PAA Laboratories, Cölbe, Germany, ${ }^{2}$ Biochrom AG, Berlin, Germany, ${ }^{3}$ Sigma-Aldrich, Steinheim, Germany 
inserts covered with Matrige ${ }^{\mathrm{TM}}$ (BD Matrigel ${ }^{\mathrm{TM}}$ Basement $^{\mathrm{B}}$ Membrane Matrix Phenol Red Free, BD Biosciences, Bedford, USA), which is a basement membrane preparation extracted from the Engelbreth-Holm-Swarm mouse sarcoma, a tumor rich in extracellular matrix proteins to include laminin, collagen IV, heparan sulfate proteoglycans, and entactin/nidogen (Kleinman et al. 1982, 1986). After a period of 7 and 14 days respectively, cultivation was stopped and the cell culture inserts were processed for microscopical examination.

Sub cultivation and visualization of the EEC grown in culture flasks was accomplished using the protocol characterized by Theuß et al. (2010). The lot of cells that was not seeded into new culture flasks was treated for microscopical exploration. In the present study, cells in transition from passage 10 to 11 (P10) and from passage 11 to 12 (P11) were examined.

Histology and cytology

Besides preparing endometrial material for isolation and cultivation of EEC, tissue samples were taken from each uterus and fixed in $4 \%$ buffered formalin for at least 24 hours, embedded in paraplast, sectioned at 3-4 $\mu \mathrm{m}$ and stained with haemalaun and eosin (H.-E.) (Romeis 1989). The same procedure was used for Millicell ${ }^{\circledR}$ membranes and not-seeded EEC, whereas the cell suspension of latter had to be centrifuged and mixed up with gelatine to form a pellet after fixation in formalin. Additionally, sections of both the pellets and the Millicell ${ }^{\circledR}$ membranes were stained with Giemsa (Romeis 1989) and evaluated cytomorphologically. Alcian blue staining of sections of the uteri as well as of the Millicell ${ }^{\circledR}$ membranes and the cell pellets at $\mathrm{pH} 2.5$ was used to identify acid mucopolysaccharides (Romeis 1989). The uterus specimens were then examined histopathologically based on Kenney and Doig (1986) and Schoon et al. (1992, 1997).
Immunohistochemistry (IHC) and immunocytochemistry (ICC)

IHC/ICC was performed using the peroxidase anti-peroxidase (PAP) method (Taylor et al. 2006). Primary antibodies, mainly anti-human antibodies that cross-reacted with equine tissues, had previously been screened to determine the optimum dilution and incubation temperature. The details of the applied antibodies are listed in table 4.

The immunolabelled sections of uterine tissue, Millice $\|{ }^{\circledR}$ membranes and cell pellets were evaluated by light microscopy to determine the proportion of positive cells and the expected location of positive immunolabelling in the cell (intranuclear: oestrogen receptor (ER) $\alpha$, progesterone receptor (PR), proliferating cell nuclear antigen (PCNA); intracytoplasmic: inhibin- $\alpha$, cytokeratin (CK) 8, 18, 19, vimentin, $\alpha$-actin, desmin, transforming growth factor (TGF)- $\alpha,-\beta 1,-\beta 2$, and $-\beta 3$ ). Immunoreactivity was assessed by examining 10 representative fields of each section under high power (x125) magnification. The number of positive cells per field was estimated semiquantitatively for the different components of the normal uterus including the luminal epithelium (LE), the excretory ducts (ED) and the glandular epithelium (GE), as well as for the EEC in vitro grown on Millicell ${ }^{\circledR}$ membranes and in cell culture flasks (represented by cell pellets), respectively. The proportion of immunolabelled cells was defined as the ratio of labelled cells to the total number of cells in 10 high powered fields and the values were expressed as 'percentage of positive cells' (PP).

\section{Results}

Gross pathology

The uteri and the ovaries of all mares did not show any noticeable pathologic alterations. All ovaries had several small

Table 4 Details of immunohistochemical/immunocytochemical methods

\begin{tabular}{|c|c|c|c|}
\hline primary antibody & epitope demasking & primary antibody dilution & $\begin{array}{l}\text { positive control } \\
\text { (horse tissue) }\end{array}$ \\
\hline mouse anti-human oestrogen receptor alpha (clone 6F 11$)^{1}(\mathrm{MC})$ & citrate buffer & $1: 20$ & endometrium \\
\hline mouse anti-human progesterone receptor $(\text { clone } 16)^{2}(\mathrm{MC})$ & citrate buffer & $1: 100$ & endometrium \\
\hline mouse anti-pig vimentin (clone V9) 3 (MC) & none & $1: 400$ & $\begin{array}{l}\text { vascular structures } \\
\text { and muscle cells }\end{array}$ \\
\hline mouse anti-human desmin (clone D33) ${ }^{3}(\mathrm{MC})$ & none & $1: 400$ & $\begin{array}{l}\text { vascular structures } \\
\text { and muscle cells }\end{array}$ \\
\hline mouse anti-human $\alpha$-actin (clone 1A4) $)^{3}(\mathrm{MC})$ & none & $1: 100$ & $\begin{array}{l}\text { vascular structures } \\
\text { and muscle cells }\end{array}$ \\
\hline mouse anti-human inhibin $\alpha(\text { clone } R 1)^{4}(M C)$ & citrate buffer & $1: 25$ & ovarian follicles \\
\hline mouse anti-human PCNA (clone PC 10)3 (MC) & none & $1: 50$ & lymph node \\
\hline mouse anti-human CK 8 (clone TS1) $)^{2}(\mathrm{MC})$ & citrate buffer & $1: 50$ & intestine \\
\hline mouse anti-human CK 18 (clone DC-10)² (MC) & citrate buffer & $1: 25$ & endometrium \\
\hline mouse anti-human CK 19 (clone b1 70)² (MC) & protease & $1: 100$ & dermis \\
\hline mouse anti-TGF- $\alpha$ (clone MF9+TG86) $(\mathrm{MC})$ & citrate buffer & $1: 100$ & endometrium \\
\hline mouse anti-TGF- $\beta 1$ (clone TB21) $)^{6}(\mathrm{MC})$ & citrate buffer & $1: 1500$ & endometrium \\
\hline rabbit anti-TGF- $\beta 2\left(M^{7}(\mathrm{PC})\right.$ & none & $1: 50$ & endometrium \\
\hline mouse anti-TGF- $\beta 3$ (clone 236-5.2) ${ }^{8}(\mathrm{MC})$ & citrate buffer & $1: 150$ & endometrium \\
\hline
\end{tabular}

The primary antibodies were applied overnight, at $4^{\circ} \mathrm{C}$; MC, monoclonal antibody; $\mathrm{PC}$, polyclonal antibody. ${ }^{1} \mathrm{Medac}$ GmbH, Wedel, Germany; ${ }^{2} \mathrm{Novocastra}, \mathrm{Newcastle}$ upon Tyne, UK; ${ }^{3}$ Dako GmbH, Hamburg, Germany; ${ }^{4}$ Biozol GmbH, Eching, Germany; 5 Dianova GmbH, Hamburg, Germany; ${ }^{6}$ Acris Antibodies GmbH, Herford, Germany; ${ }^{7}$ Santa Cruz Biotechnology, Santa Cruz, CA, USA; ${ }^{8}$ Merck Chemicals, Darmstadt, Germany 
follicles and Corpora albicantia. The ovaries of mare 1 and mare 3 showed unilateral one Corpus luteum, while mare 2 had one Corpus haemorrhagicum in one of the ovaries. Therefore, we stated mare 1 and mare 3 to be in interoestrus, and mare 2 to be postovulatory.

\section{Histology and cytology}

The uteri of all mares showed a mild to moderate endometrosis and a mild to moderate angiosclerosis. Consistent with the ovarian findings, the functional morphology of the endometrium of mare 1 and 3 showed a secretion morphology and mare 2 showed a morphology consistent with the transition from proliferation to secretion phase.

The EEC of sectioned Millicell ${ }^{\circledR}$ membrane specimens revea-

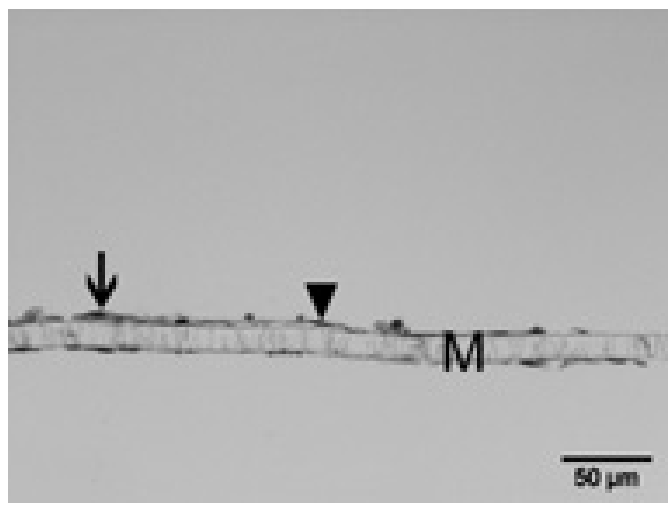

Fig. 1 EEC (origin: mare 3) on uncovered Millicell ${ }^{\circledR}$ membrane (M), MFBS, PO, day 14 of culture, monolayer, two morphologically different cell types are found: cell type 1 (arrow), cell type 2 (arrowhead) (H.-E. staining)

EEC (Ursprung: Stute 3) auf unbeschichteter Millicell ${ }^{\circledR}$-Membran (M), MFBS, PO, Kulturtag 14, Monolayer, zwei morphologisch unterschiedliche Zelltypen treten auf: Zelltyp 1 (Pfeil), Zelltyp 2 (Pfeilspitze) (H.-E.-Färbung)

led three different types of growth patterns: monolayer (Fig. 1), multilayered growth (Fig. 2) and dome growth (Fig. 3). However, we posit multilayered growth to be part of the boundary area of dome growth. Two morphologically different cell types can be found in monolayer areas (Fig. 1).
Detailed cytological attributes of membrane-grown EEC are listed in table 5, which does not show any apparent difference between cell type 1 in monolayer areas and cells in multilayer or dome areas. All membranes revealed all different

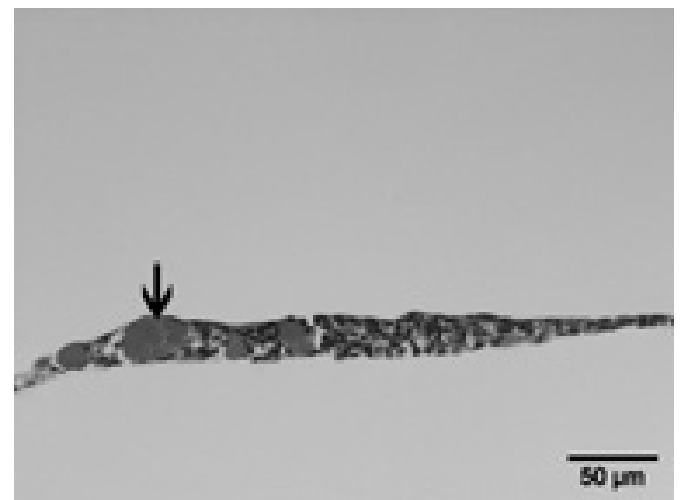

Fig. 2 EEC (origin: mare 3) on uncovered Millicell ${ }^{\circledR}$ membrane, MHS1, PO, day 14 of culture, multilayered growth; antra filled with finely granular eosinophilic material (arrow) (H.-E. staining) EEC (Ursprung: Stute 3) auf unbeschichteter Millicell ${ }^{\circledR}$-Membran, MHS 1, PO, Kulturtag 14, mehrschichtiges Wachstum; Hohlräume, gefüllt mit feingranulärem eosinophilen Material (Pfeil) (H.-E.-Färbung)

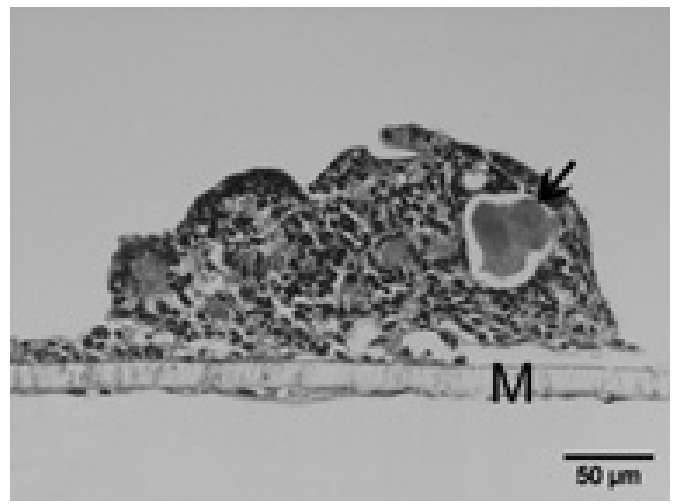

Fig. 3 EEC (origin: mare 3) on uncovered Millicell ${ }^{\circledR}$ membrane (M), MHS2, P0, day 14 of culture, dome growth; antra filled with finely granular eosinophilic material (arrow) (H.-E. staining)

EEC (Ursprung: Stute 3) auf unbeschichteter Millicell ${ }^{\circledR}$-Membran (M), MHS2, PO, Kulturtag 14, "kuppenförmiges" Wachstum; Hohlräume, gefüllt mit feingranulärem eosinophilen Material (Pfeil) (H.-E.-Färbung)

Table 5 Cytomorphology of EEC in vitro, cultured on Millicell ${ }^{\circledR}$ PCF culture inserts

\begin{tabular}{|c|c|c|c|}
\hline & \multicolumn{2}{|c|}{ monolayer } & \multirow{2}{*}{ multilayered or dome growth } \\
\hline & cell type 1 & cell type 2 & \\
\hline cell shape & round-oval to polygonal & spindle shaped & round-oval to polygonal \\
\hline \multicolumn{4}{|l|}{$\underline{\text { nucleus }}$} \\
\hline shape & round to oval & elongated-oval & round to oval \\
\hline amount of chromatin & hypo-/hyperchromatic & mostly hyperchromatic & hypo-/hyperchromatic \\
\hline number of nucleoli & $1-2$ (mostly 1$)$ & none & $1-2$ (mostly 1$)$ \\
\hline mitotic figures & very sporadic & very sporadic & very sporadic \\
\hline \multicolumn{4}{|l|}{ cytoplasm } \\
\hline amount & few to moderate & few & few to moderate \\
\hline staining & dark eosinophilic & dark eosinophilic & dark eosinophilic \\
\hline structure & $\begin{array}{c}\text { mostly honeycombed, } \\
\text { partly vacuolized }\end{array}$ & $\begin{array}{c}\text { mostly honeycombed, } \\
\text { partly vacuolized }\end{array}$ & $\begin{array}{c}\text { mostly honeycombed, } \\
\text { partly vacuolized }\end{array}$ \\
\hline cell borders & indistinct & indistinct & indistinct \\
\hline
\end{tabular}


types of growth patterns. Regarding multilayered and dome growth, cells partially enclose irregular shaped antra, filled with an eosinophilic material, either homogeneous or finely granular (Fig. 2, 3). Using Giemsa staining the material appears either lightly pink or is not stained at all. All cells on Millicell ${ }^{\circledR}$ membranes did not show any polarization.

The cell pellet sections of $\mathrm{P} 10$ and $\mathrm{P} 11$ revealed two different cell types, as indicated by Theuß et al. (2010). Their morphological characteristics are stated in table 6.

Alcian blue staining of the uteri specimens dyed almost all cells of the luminal epithelium but only very few excretory duct cells. Neither cells of the glandular epithelium in situ nor any cells in vitro nor the antra filling material found on Millicell ${ }^{\circledR}$ membranes were alcian blue positive. The details are summarized in table 7.
Immunohistochemistry and immunocytochemistry

All immunohistochemical and immunocytochemical findings are summarized in table 7 .

The two morphologically different cell types found in vitro on Millicell ${ }^{\circledR}$ membranes and in the cell pellets, as well as the three different growth patterns of membrane-grown EEC, do not show apparent differences pertaining to immunolabelling properties.

Some of the culture conditions generate an in vitro expression similar to the one seen in the endometrium in situ, especially in the glandular epithelium. Numerous cells showed labelling for CK 19 (Fig. 4), TGF- $\beta 1$ and TGF- $\beta 3$ (Fig. 5) under all investigated conditions.

Table 6 Cytomorphology of pelletized EEC after cultivation in cell culture flasks (P10, P1 1)

\begin{tabular}{|c|c|c|}
\hline & cell type 1 & cell type 2 \\
\hline cell shape & round-oval & mostly round-oval, partly polygonal \\
\hline \multicolumn{3}{|l|}{$\underline{\text { nucleus }}$} \\
\hline number & 1 & mostly 1 , occasionally 2 , rarely 3 \\
\hline shape & mostly round-oval, partly polygonal & mostly round-oval, partly polygonal \\
\hline amount of chromatin & hypo-/hyperchromatic & hypo-/hyperchromatic \\
\hline number of nucleoli & 1 & $1-2$ \\
\hline mitotic figures & very sporadic & very sporadic \\
\hline \multicolumn{3}{|l|}{ cytoplasm } \\
\hline amount & few & moderate to abundant \\
\hline staining & eosinophilic to dark eosinophilic & eosinophilic to dark eosinophilic \\
\hline structure & finely honeycombed & mostly finely honeycombed, partly vacuolized \\
\hline cell borders & distinct & distinct \\
\hline
\end{tabular}

Table 7 Immunolabelling and alcian blue staining of epithelial cells in the endometrium and after cultivation

\begin{tabular}{|c|c|c|c|c|c|c|c|c|c|c|c|c|c|c|}
\hline \multirow{4}{*}{$\begin{array}{l}\text { PP (\%) of } \\
\text { labelled } \\
\text { cells for }\end{array}$} & \multicolumn{3}{|c|}{ endometrium in situ } & \multicolumn{9}{|c|}{ cells cultured on Millicell ${ }^{\circledast}$ PCF, PO } & \multirow{2}{*}{\multicolumn{2}{|c|}{$\begin{array}{l}\text { cells cultured in } \\
\text { cell culture flasks } \\
\text { pellet at the end of }\end{array}$}} \\
\hline & \multirow[b]{3}{*}{ LE } & \multirow[b]{3}{*}{ ED } & \multirow[b]{3}{*}{ GE } & \multicolumn{8}{|c|}{ uncovered } & \multirow{3}{*}{$\begin{array}{c}\text { Matrigel }^{\mathrm{TM}} \\
\text { day } 14 \\
\text { MFBS }\end{array}$} & & \\
\hline & & & & \multicolumn{4}{|c|}{ day 7 , various media } & \multicolumn{4}{|c|}{ day 14 , various media } & & P10 & P11 \\
\hline & & & & MFBS & MHSI & MHS2 & MHS3 & MFBS & MHSI & MHS2 & MHS3 & & & \\
\hline$E R \alpha$ & 0 & 0 & $10-40^{*}$ & 0 & 0 & 0 & 0 & 0 & 0 & 0 & 0 & 0 & 60 & 60 \\
\hline PR & $0-5$ & $0-5$ & $0-90^{*}$ & 0 & 0 & 0 & 0 & 0 & 0 & 0 & 0 & 0 & 0 & 0 \\
\hline PCNA & $0-10$ & $0-10$ & $5-20$ & $<5$ & $<5$ & $<5$ & $<5$ & $<5$ & 0 & 0 & 0 & $<5$ & $<5$ & $<5$ \\
\hline inhibin- $\alpha$ & 0 & $0-<5$ & $5-70^{*}$ & 0 & 0 & 0 & 0 & 0 & 0 & 0 & 0 & 0 & 0 & 0 \\
\hline CK 8 & 0 & 0 & $5-30 *$ & 0 & 0 & 0 & 0 & 0 & 0 & 0 & 0 & 0 & 20 & 20 \\
\hline CK 18 & 0 & 0 & $5-30 *$ & 10 & 0 & 0 & 0 & 0 & 0 & 0 & 0 & 0 & 10 & 10 \\
\hline CK 19 & $80-$ & $80-$ & $50-$ & 90 & 70 & 90 & 70 & -- & 90 & 70 & 80 & 90 & 99 & 99 \\
\hline vimentin & $0-30 *$ & 0 & $0-<5$ & $<5$ & $<5$ & $<5$ & 5 & 10 & $<5$ & $<5$ & $<5$ & $<5-15$ & $<5$ & 15 \\
\hline$\alpha$-actin & 0 & 0 & 0 & 70 & 60 & 30 & 40 & 60 & 80 & 70 & 20 & $90-95$ & 0 & 0 \\
\hline desmin & 0 & 0 & 0 & 0 & 0 & 0 & 0 & 0 & 0 & 0 & 0 & 0 & 0 & 0 \\
\hline TGF- $\alpha$ & 0 & 0 & 0 & 10 & 10 & 20 & 10 & 0 & $<5$ & $<5$ & $<5$ & 0 & 10 & 10 \\
\hline TGF- $\beta 1$ & $<5$ & $<5$ & 95 & 95 & 50 & 70 & 70 & 80 & 70 & 90 & 70 & 90 & 70 & 70 \\
\hline TGF- $\beta 2$ & $10-90^{*}$ & $10-90 *$ & 10 & 10 & 20 & 20 & 30 & 40 & 30 & 30 & 20 & 30 & 80 & 90 \\
\hline TGF- $\beta 3$ & $20-80^{*}$ & $20-90^{*}$ & $50-90 *$ & 90 & 98 & 98 & 100 & 95 & 98 & 95 & 90 & $90-100$ & 80 & 80 \\
\hline alcian blue & 90 & 5 & 0 & 0 & 0 & 0 & 0 & 0 & 0 & 0 & 0 & 0 & 0 & 0 \\
\hline
\end{tabular}

-- Data not available. * Variable immunolabelling regarding the percentage of positive cells (PP). 
In contrast, much less cells in the pellets of P10 and P11 (MFBS+A) labelled for CK 8 and 18 while virtually none of the membrane-grown cells expressed these two intermediate filaments. Only a few EEC reacted positively with CK 18 antibodies. These cells were taken at culture day 7 and grown in MFBS on uncovered Millicell ${ }^{\circledR}$ membranes.

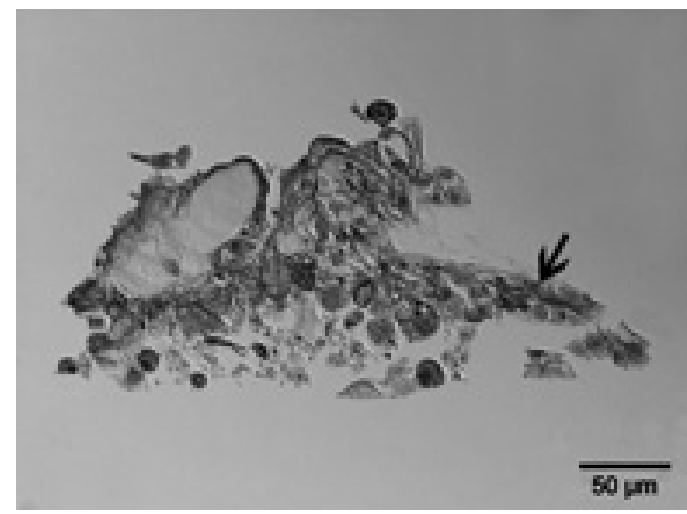

Fig. 4 EEC (origin: mare 1) on Matrigel ${ }^{T M}$-covered Millicell ${ }^{\circledR}$ membrane, MFBS, PO, day 14 of culture, dome growth, gradually variable intracytoplasmic diffuse homogeneous to honeycombed expression pattern of CK 19 (arrow) (ICC, Nomarski-interferencecontrast)

EEC (Ursprung: Stute 1) auf Matrigel ${ }^{\text {TM }}$-beschichteter Millicell ${ }^{\circledR}$-Membran, MFBS, PO, Kulturtag 14, "kuppenförmiges" Wachstum; graduell variables intrazytoplasmatisches diffuses homogenes bis wabiges Expressionsmuster von CK 19 (Pfeil) (Immunzytologie, NomarskiInterferenzkontrast)

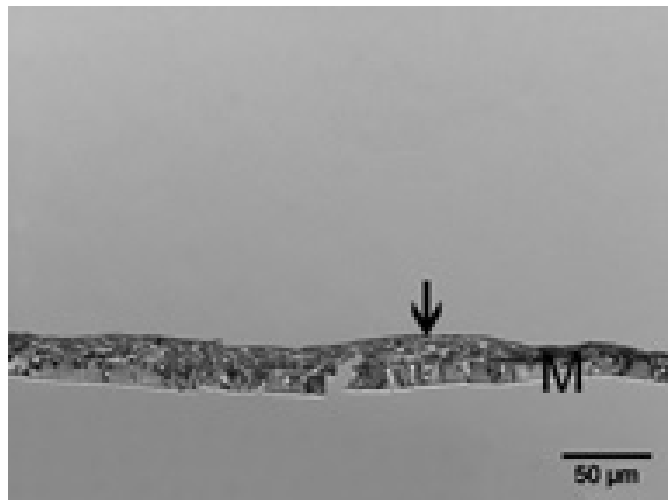

Fig. 5 EEC (origin: mare 3) on uncovered Millicell ${ }^{\circledR}$ membrane (M), MHS2, P0, day 7 of culture, multilayered growth, predominantly moderate to strong expression of TGF- $\beta 3$, intracytoplasmic diffuse homogeneous to honeycombed expression pattern (arrow) (ICC, Nomarski-interference-contrast)

EEC (Ursprung: Stute 3) auf unbeschichteter Millicell ${ }^{\circledR}$-Membran (M), MHS2, PO, Kulturtag 7, mehrschichtiges Wachstum; überwiegend mittel- bis hochgradige Expression von TGF- $\beta 3$, intrazytoplasmatisches diffuses homogenes bis wabiges Expressionsmuster (Pfeil) (Immunzytologie, Nomarski-Interferenzkontrast)

A high percentage of pelletized cells of $\mathrm{P} 10$ and $\mathrm{P} 11$ are characterized by the expression of TGF- $\beta 2$. EEC on Millicell ${ }^{\circledR}$ membranes have a lower rate of positive cells.

TGF- $\alpha$, which is not expressed by any subpopulation of EEC in situ, shows positive reactions in vitro in a few P10- and P1 1 -cells as well as in several membrane-grown cells on culture day 7 (Fig. 6). The number of immunolabelled cells on day 14 is very low regardless of the culture media and the membrane covering. Like TGF- $\alpha, \alpha$-actin is not detectable immunohistochemically in EEC in situ. The same is found in
P10- and P11-pellets in vitro, but cells grown on Millicell ${ }^{\circledR}$ membranes (Fig. 7) show positive reactions. Expression of $E R \alpha, P R$ and inhibin- $\alpha$ can be observed in EEC in situ to some extent, but there was not any noticeable labelling for these markers in vitro, apart from P10- and P1 1-pellet cells concerning ER $\alpha$ (Fig. 8). Notwithstanding the common expression

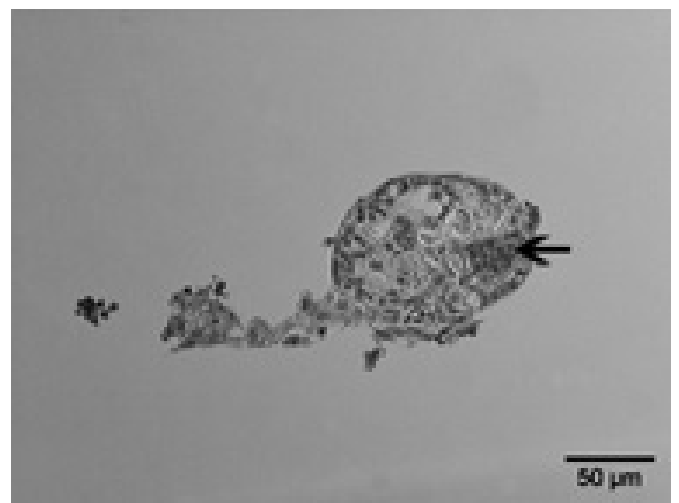

Fig. 6 EEC (origin: mare 3) on uncovered Millicell ${ }^{\circledR}$ membrane, MHS1, PO, day 7 of culture, dome growth, predominantly moderate to strong expression of TGF- $\alpha$, intracytoplasmic diffuse homogeneous to honeycombed expression pattern (arrow) (ICC, Nomarskiinterference-contrast)

EEC (Ursprung: Stute 3) auf unbeschichteter Millicell ${ }^{\circledR}-$ Membran, MHS 1, PO, Kulturtag 7, "kuppenförmiges" Wachstum; überwiegend mittel- bis hochgradige Expression von TGF- $\alpha$, intrazytoplasmatisches diffuses homogenes bis wabiges Expressionsmuster (Pfeil) (Immunzytologie, Nomarski-Interferenzkontrast)

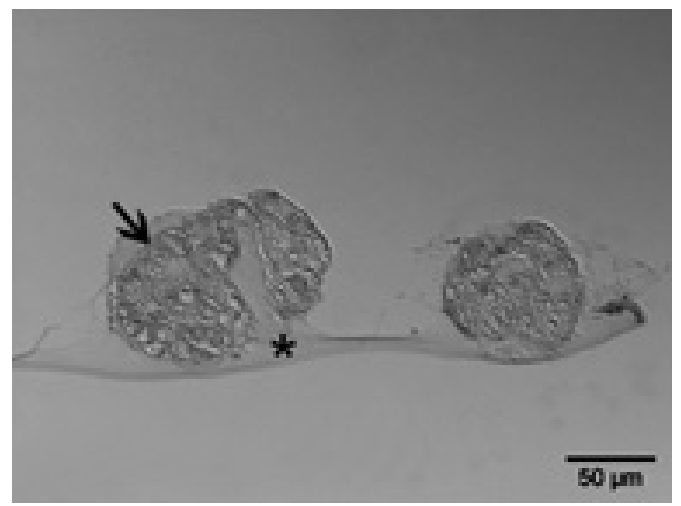

Fig. 7 EEC (origin: mare 1) on Matrigel ${ }^{\mathrm{TM}}$ (asterisk)-covered Millicell $^{\circledR}$ membrane, MFBS, PO, day 14 of culture, dome growth, gradually variable intracytoplasmic diffuse homogeneous to honeycombed expression pattern of $\alpha$-actin (arrow) (ICC, Nomarski-interference-contrast)

EEC (Ursprung: Stute 1) auf Matrige ${ }^{\mathrm{TM}}$ (Stern)-beschichteter Millicell ${ }^{\circledR}$-Membran, MFBS, PO, Kulturtag 14, "kuppenförmiges" Wachstum; graduell variables intrazyłoplasmatisches diffuses homogenes bis wabiges Expressionsmuster von $\alpha$-Aktin (Pfeil) (Immunzytologie, Nomarski-Interferenzkontrast)

pattern in situ being predominantly intranuclear, more than half of the cells in vitro were immunolabelled intracytoplasmic, but none intranuclear.

EEC in vitro stained for PCNA only sporadically without any obvious differences between the various media.

Vimentin-positive cells could be found in up to $15 \%$ of the cells of in vitro specimens (Fig. 9) with an atypical plaque shaped expression pattern, compared to luminal epithelium in situ (Fig. 10). 
Desmin is neither in situ nor in vitro expressed by EEC. All in all, EEC cultured in MFBS +A (P10-and P1 1 -pellets) showed expression patterns that were most similar to those of endometrial glandular epithelium in situ. Therefore, MFBS $+\mathrm{A}$ is regarded to be the most suitable medium for cultivation of EEC in vitro.

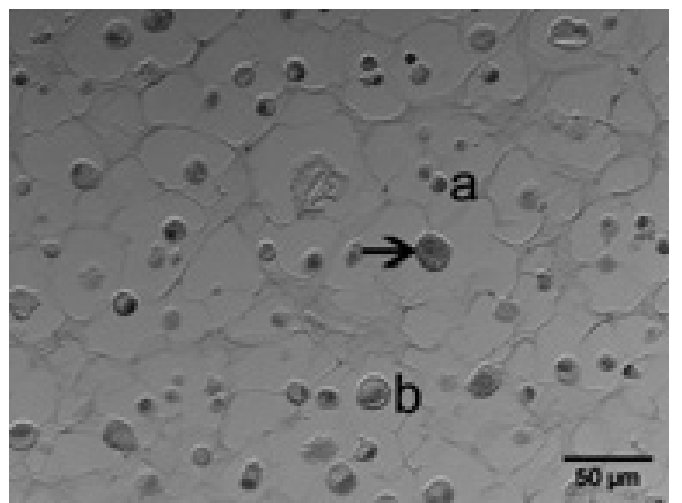

Fig. 8 EEC (origin: mare 2), cell pellet (cells were grown in cell culture flasks), MFBS $+A, P 10$, gradually variable intracytoplasmic diffuse or focal finely honeycombed expression pattern of ER $\alpha$ (arrow), two morphologically different cell types are found: cell type 1 (a), cell type 2 (b) (ICC, Nomarski-interference-contrast)

EEC (Ursprung: Stute 2), Zellpellet (Zellen wurden in Zellkulturflaschen gezüchtet), MFBS $+A, P 10$, graduell variables intrazytoplasmatisches diffuses oder fokales feinwabiges Expressionsmuster von ER $\alpha$ (Pfeil), zwei morphologisch unterschiedliche Zelltypen treten auf: Zelltyp 7 (a), Zelltyp 2 (b) (Immunzytologie, Nomarski-Interferenzkontrast)

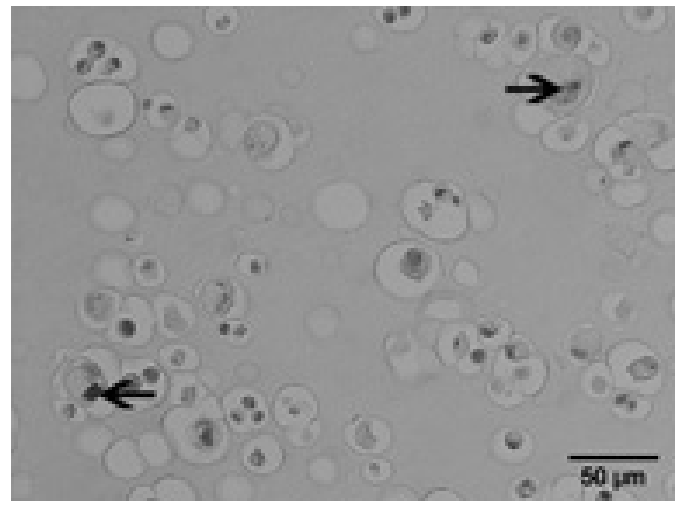

Fig. 9 EEC (origin: mare 2), cell pellet (cells were grown in cell culture flasks), MFBS $+A, P 11$, gradually variable atypical intracytoplasmic plaque shaped expression pattern of vimentin (arrows) (ICC, Nomarski-interference-contrast)

EEC (Ursprung: Stute 2), Zellpellet (Zellen wurden in Zellkulturflaschen gezüchtet), MFBS $+A, P 11$, graduell variables atypisches intrazytoplasmatisches plaqueförmiges Expressionsmuster von Vimentin (Pfeile) (Immunzytologie, Nomarski-Interferenzkontrast)

\section{Discussion}

Summing up the findings of gross examination of the ovaries, functional morphology of the endometrium specimens including the immunoreactivity for ER $\alpha$, PR (Aupperle et al. 2000) and PCNA, it can be emphasized that all of the three mares had been in postovulatory to early interoestrus phase at day of death. The state of the endometrial cycle of the mare at point of isolation of the EEC for culture did not have any obvious influence on morphological and immunocytochemical characteristics in vitro. Concerning PCNA expression, it remains unclear why only few EEC in vitro were immunolabelled in the present study.

Buschatz (2007) reports on monolayer, multilayered and dome growth of EEC in vitro grown on Matrigel ${ }^{\mathrm{TM}}$-covered cell culture inserts. Concerning monolayer areas only cuboi-

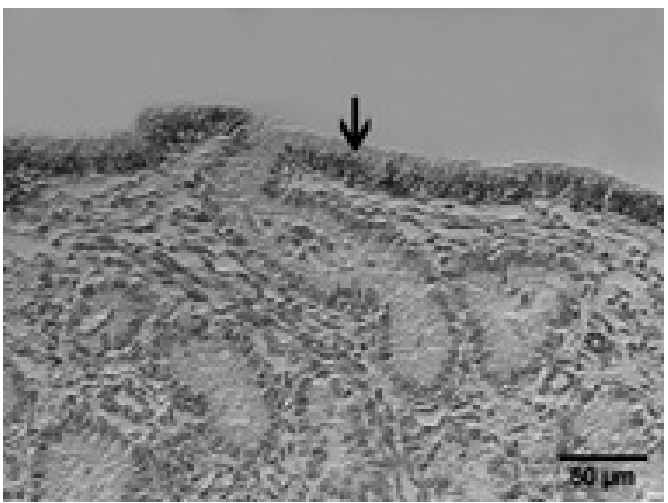

Fig. 10 Endometrium in situ (mare 1), moderate to strong expression of vimentin in luminal epithelium (arrow) (diffuse, basal and perinuclear expression patterns) (IHC, Nomarski-interference-contrast)

Endometrium in situ (Stute 1), mittel- bis hochgradige Expression von Vimentin im luminalen Epithel (Pfeil) (diffuses, basales und perinukleäres Expressionsmuster) (Immunhistologie, Nomarski-Interferenzkontrast)

dal to columnar epithelial cells are mentioned. The same morphology was recognized in dome growth areas, where these epithelial cells surrounded irregular shaped antra. In multilayered growth, no polarization of EEC was noticed. In contrast to these results of Buschatz (2007), only non-polarized cells were found on Millicell ${ }^{\circledR}$ membranes in the present study. Moreover, cuboidal to columnar cells could not be observed in monolayer areas and antra were detectable both on Matrigel ${ }^{\mathrm{TM}}$ covered cell culture inserts and on all uncovered ones. The origin of the substance traceable in these antra therefore remains unclear. It might be considered as some kind of extracellular matrix or amorphous cellular debris. Zhang and Davis (2000) mention the formation of cavities by porcine uterine gland cells due to the degeneration of cytoplasm in the central cells when cocultured with stromal cells. Concerning a stromal cell contamination, this theory should be taken into account, but it is unlikely as most of the EEC showed positive reaction for CK 19 in our study, while none of them reacted positively for desmin. Lack of polarization might be due to lack of basement membrane components on uncovered Millicell ${ }^{\circledR}$ inserts, but regarding Matrigel $^{\mathrm{TM}}$ covered inserts it remains obscure. Several authors refer to the need of extracellular matrix to maintain polarization of animal endometrial epithelial cells in vitro (Munson et al. 1990, Zhang and Davis 2000). However, cultivation on plastic surfaces or uncovered Millicell ${ }^{\circledR}$ membranes possesses the advantage of lacking the influence of Matrigel ${ }^{\mathrm{TM}}$ properties.

In agreement with Buschatz (2007) and Theuß et al. (2010) concerning cultivation of EEC on uncovered plastic surfaces, two morphologically different cell types were detectable in the cell pellets of $\mathrm{P} 10$ and $\mathrm{P} 11$.

Absent staining for alcian blue in EEC in vitro compared to the endometrial epithelia in situ suggests that in vitro cells in this study are of glandular origin. Alternatively, cells of the 
uterine luminal epithelium could possibly be among the cultured cells but do not produce any acid mucopolysaccharides in vitro.

CK 8, 18 and 19 have been used by Mylonas et al. (2000a) to verify the purity of human EEC in vitro. As CK 8 and 18 are only sparsely expressed by equine uterine glandular epithelial cells in situ, and as EEC in vitro hardly showed positive reaction for CK 8 and 18, these markers seem unsuitable to check the culture purity of EEC of mares. Except for the pelletized cells, none of the cells grown in Millicell ${ }^{\circledR}$ inserts showed labelling for CK 8. Expression of CK 18 is likewise except for one cell population on day 7 grown on uncovered membranes. This might be due to the utilized medium (MFBS). However, MFBS+A seems to induce an immunoreactivity even more similar to that of the endometrium in situ. In this study many EEC in situ and in vitro were immunolabelled for CK 19. Therefore, we agree with Mylonas et al. (2000a) and propose staining for CK 19 as an essential attribute to verify the epithelial origin of endometrial cells of mares in vitro.

It is well-known that EEC in vitro may show positive reaction for vimentin. This feature is observed for human (ClassenLinke et al. 1997), canine (Galabova-Kovacs et al. 2004), bovine (Munson et al. 1988) and porcine (Zhang et al. 1991) EEC. Buschatz (2007) demonstrates immunolabelling for vimentin in equine EEC both grown on plastic surfaces and on Matrigel ${ }^{\text {TM }}$ covered cell culture inserts. Similar results were achieved in the present study. In addition, we could detect vimentin in EEC grown on uncovered Millicell ${ }^{\circledR}$ membranes as well. Therefore, vimentin does not seem to be an adequate marker to distinguish between equine EEC and ESC in vitro. Opposing the argument that vimentin-positive cells might be due to stromal cell contamination, an identification of cells as epithelial cells at least in the cell pellets of P10 and P1 1 has been carried out observing their morphology during the process of cultivation as described by Theu $B$ et al. (2010) as well. Franke et al. (1979) mention vimentin occurrence in epithelial cells in connection with cell proliferation or as an adaptation to in vitro growth. Vimentin expression in EEC in vitro is regarded as a probable sign of unsuitable environmental conditions by Buschatz (2007). In contrast to the circumstances in the human endometrium (Matthews et al. 1992), Aupperle et al. (2004) negate a physiological expression of vimentin in endometrial epithelia of mares, but revealing glandular expression of vimentin in equine endometrosis mostly with an intracytoplasmic basal pattern. We noticed a predominantly atypical intracytoplasmic plaque-shaped expression pattern in vitro, but as there is lack of polarization of the cells cultured in this study, no conclusion can be drawn concerning any similarities to the expression pattern in glands affected by endometrosis. In one of the uteri about $30 \%$ of cells of unaltered luminal epithelium in situ were found labelling for vimentin with different expression patterns (intracytoplasmic: diffuse, basal, perinuclear). Regarding this, further investigations are necessary with larger numbers of animals, since this property had not been reported in mares before.

Desmin is another intermediate filament that is not found in EEC of mares in situ (Aupperle et al. 2004). We can confirm this and add that EEC in vitro do not express desmin, too.
Immunolabelling for $\alpha$-actin in situ is found in ESC within endometrotic areas, confirming the results of Raila (2000). We did not notice any labelled uterine epithelia in situ. The same can be stated with regard to the pelletized cells in this study. On the contrary, a large number of cells grown on Millicell ${ }^{\circledR}$ membranes were labelled with the cause remaining unclear. Contamination by ESC seems to be quite improbable, as cultured cells generally labelled for CK 19 in a high percentage, which is characteristic for EEC in situ and in vitro. Moreover, none of the examined in vitro specimens showed desmin expression, which is one of the characteristics of at least a certain proportion of equine ESC in vitro (Buschatz 2007). It can be restated that the immunocytochemical characteristics of EEC grown in MFBS $+\mathrm{A}$ are more similar to those in situ than the expression pattern of cells grown in all of the four other media we tested, as already pointed out regarding CK 8, 18 and 19.

Intranuclear ER $\alpha$ - and PR-expression in uterine epithelia in situ depends on the stage of the mare's endometrial cycle, as described by Brunckhorst et al. (1991) and Aupperle et al. (2000), finding only intranuclear expression of both hormone receptors. Buschatz (2007) was not able to demonstrate both receptors in equine EEC in vitro. Regarding PR, our study equates these results, but in contrast about $60 \%$ of the cells in P10- and P1 1-pellets were labelled intracytoplasmic for $E R \alpha$, while none of the cells showed the common intranuclear immunolabelling. Both receptors are synthesized intracytoplasmic and attain to the nucleus via active transport mechanisms depending on adenosine triphosphate (ATP) and temperature (Guichon-Mantel et al. 1996). A continuous change-over of diffusion from nucleus to cytoplasm and active transport back to the nucleus exists (Guichon-Mantel et al. 1991 und 1996, Yoneda 2000). For these reasons, lack of energy, e. g. due to the procedure of passaging, might be the reason of intracytoplasmic labelling for ERa in the pelletized cells in the present study. Anyway, it still remains unclear why there is no labelling detectable for PR. Temperature should be considered as a criterion even if it is inprecise. However, among the five media tested only cells grown in MFBS+A showed positive immunolabelling for ERa at all. Therefore, further investigations have to be carried out, using MFBS +A and hormone supplements in order to stimulate hormone receptor expression.

Human EEC in vitro secrete inhibin- $\alpha$, which was detected only by enzyme immunoassay by Mylonas et al. (2003), but not by IHC. We could show immunolabelling of endometrial glandular epithelia for inhibin- $\alpha$ in situ, but there was no labelling recognizable in the in vitro specimens. This might be due to the fact that IHC is not sensitive enough. With regard to CK 8 and 18 as well as to $\alpha$-actin and ER $\alpha$ we stated MFBS $+A$ to be a suitable culture medium to grow cells with characteristics similar to those in situ. Acting on this assumption, equine EEC might possibly lose the ability to synthesize inhibin- $\alpha$, at least in higher passages. Therefore, further investigations are necessary using either primary cultures grown in MFBS +A or lower passages as well as measuring secreted inhibin within the culture medium using a more sensitive detection method.

As cultured cells in vitro are proliferating cells, the aim of examination of TGF- $\alpha,-\beta 1,-\beta 2$ and $-\beta 3$ was to get first insights 
into the expression of these growth factors in EEC in vitro. TGF- $\alpha$ is not expressed by any endometrial epithelia of the mare in situ, while ESC are immunolabelled for TGF- $\alpha$, as described by Stief (2006) as well. As aforementioned, the results of the immunocytochemical examination regarding CK 19 and desmin rule out a contamination with stromal cells to a very high probability. Stress due to procedures of cell isolation or sub cultivation might cause higher TGF- $\alpha$ expression in vitro in those specimens that were examined after 7 days of culture and during transition to a further passage (P10-and $\mathrm{P} 11$-pellets) in terms of a closer chronological relation to stressing procedures.

In the present study, TGF- $\beta 1$ and $-\beta 3$ showed similar immunolabelling in vitro and in situ, at least regarding the glandular epithelium. A high percentage of EEC reacted positively for these two growth factors, without any obvious dependency on the culture media (including their hormone concentrations), the duration of culture or the growth surface.

However, immunolabelling for TGF- $\beta 2$ showed a different reaction concerning EEC grown on Millicell ${ }^{\circledR}$ membranes. In cells of $\mathrm{P} 10$ and $\mathrm{P} 11$ grown in MFBS $+\mathrm{A}$, higher amounts of cells labelled for TGF- $\beta 2$, comparable to TGF- $\beta 1$ and $-\beta 3$. As there is a broad variation of all endometrial epithelia in situ regarding the expression of TGF- $\beta 2$, it remains unclear whether labelling for this growth factor in vitro is more similar to the situation in situ using MFBS $+A$ as with one of the other media we tested.

Summing up, equine EEC grown in MFBS + A show immunocytochemical characteristics in vitro which are similar to those of endometrial epithelia in situ, especially in the glandular epithelium. In contrary, EEC grown in one of the four other media show different immunocytochemical characteristics. Therefore, we regard MFBS $+\mathrm{A}$ to be an optimal culture medium concerning the comparability of in vitro results to the in situ situation.

Long-term objective is to survey the results of this study by means of higher numbers of samples, utilizing mares in different stages of the reproductive cycle. Equine ESC should be examined in the same manner as equine EEC in the present study to clear up the reaction pattern of a second important endometrial cell component and to obtain further aetiological examinations concerning equine endometrosis.

\section{Acknowledgements}

This work was supported financially by the Ernst-von-WeberStiftung.

\section{Literature}

Arthur G. H. (1958) An analysis of the reproductive function of mares based on post-mortem examination. Vet. Rec. 70, 682-686

Aupperle H., Özgen S., Schoon H.-A., Schoon D., Hoppen H. O., Sieme H. and Tannapfel A. (2000) Cyclical endometrial steroid hormone receptor expression and proliferation intensity in the mare. Equine Vet. J. 32, 228-232

Aupperle H., Schoon D. and Schoon H.-A. (2004) Physiological and pathological expression of intermediate filaments in the equine endometrium. Res. Vet. Sci. 76, 249-255
Brady H. A., Burghardt R. C., Evans J. W., Blanchard T. L. and Varner D. D. (1992) Intercellular Communication in Mare Endometrial Epithelium Isolated During Estrus and Diestrus. Equine Vet. Sci. 12, 227-232

Brady H. A., Burghardt R. C., Evans J. W., Blanchard T. L., Varner D. D. and Bruemmer J. E. (1993) Model System for the Study of Uterine Trophoblast Interactions in the Mare. Equine Vet. Sci. 13, 506-511

Brunckhorst D., Schoon H.-A., Bader H. and Sieme H. (1991) Morphologische, enzym- und immunhistochemische Charakteristika des endometrialen Zyklus bei der Stute. Fertilität. 7, 44-51

Burghardt R. C., Barhoumi R., Sewall T. C. and Bowen J. A. (1995) Cyclic AMP Induces Rapid Increases in Gap Junction Permeability and Changes in the Cellular Distribution of Connexin43. J. Membrane Biol. 148, 243-253

Buschatz S. (2007) Etablierung und Charakterisierung einer Zellkultur equiner endometrialer Epithel- und Stromazellen. Med. vet. Diss. Universität Leipzig

Classen-Linke I., Kusche M., Knauthe R. and Beier H. M. (1997) Establishment of a human endometrial cell culture system and characterization of its polarized hormone responsive epithelial cells. Cell Tissue Res. 287, 171-185

Day W. E., Bowen J. A., Barhoumi R., Bazer F. W. and Burghardt R. C. (1998) Endometrial connexin expression in the mare and pig: evidence for the suppression of cell-cell communication in uterine luminal epithelium. Anat. Rec. 251, 277-285

Franke W. W., Schmid E., Winter S., Osborn M. and Weber K. (1979) Widespread occurrence of intermediate-sized filaments of the vimentin-type in cultured cells from diverse vertebrates. Exp. Cell Res. 123, 25-46

Freshney R. I. (1990) Tierische Zellkulturen. Berlin: de Gruyter

Galabova-Kovacs G., Walter I., Aurich C. and Aurich J. E. (2004) Steroid receptors in canine endometrial cells can be regulated by estrogen and progesterone under in vitro conditions. Theriogenology 61, 963-976

Groothuis P. G., McGuire W. J., Vallett J. L., Grieger D. M. and Davis D. L. (2002) Retinol and estradiol regulation of retinol binding protein and prostaglandin production by porcine uterine epithelial cells in vitro. J. Anim. Sci. 80, 2688-2694

Guichon-Mantel A., Delabre K., Lescop P. and Milgrom E. (1996) Intracellular traffic of steroid hormone receptors. J. Steroid Biochem. Molec. Biol. 56, 3-9

Guichon-Mantel A., Lescop P., Christin-Maitre S., Loosfelt H., PerrotApplanat M. and Milgrom E. (1991) Nucleocytoplasmic shuttling of the progesterone receptor. EMBO J. 10, 3851-3859

Kenney R. M., Condon W., Ganjam V. K. and Channing C. (1979) Morphological and biochemical correlates of equine ovarian follicles as a function of their state of viability or atresia. Reprod. Fertil. 27 (Suppl.), 163-171

Kenney R. M. and Doig P. A. (1986) Equine Endometrial Biopsy. In: Morrow D. A., editor. Current Therapy in Theriogenology. 2nd ed. Philadelphia: WB Saunders; p. 723-729

Kleinman H. K., McGarvey M. L., Hassell J. R., Star V. L., Cannon F. B., Laurie G. W. and Martin G. R. (1986) Basement membrane complexes with biological activity. Biochem. 25, 312-318

Kleinman H. K., McGarvey M. L., Liotta L. A., Robey P. G., Tryggvason K. and Martin G. R. (1982) Isolation and characterization of type IV procollagen, laminin, and heparan sulfate proteoglycan from the EHS sarcoma. Biochem. 21, 6188-6193

Matthews C. J., Redfern C. P., Hirst B. H. and Thomas E. J. (1992) Characterization of human purified epithelial and stromal cells from endometrium and endometriosis in tissue culture. Fertil. Steril. 57, 990-997

Munson L., Chandler K. S. and Schlafer D. H. (1988) Cultivation of bovine fetal and adult endometrial epithelial cells. Tissue Cult. Methods. 11, 129-133

Munson L., Wilkinson J. E. and Schlafer D. H. (1990) Effects of substrata on the polarization of bovine endometrial epithelial cells in vitro. Cell Tissue Res. 261, 155-161 
Mylonas I., Makovitzky J., Richter D. U., Jeschke U., Briese V. and Friese K. (2000a) Expression of cytokeratins and vimentin in normal human endometrial cells in vitro: an immunohistochemical analysis on isolated glandular epithelial cells. Anticancer Res. 20, 5125-5128

Mylonas I., Speer R., Makovitzky J., Richter D. U., Briese V. and Jeschke U. (2000b) Immunohistochemical analysis of steroid receptors and glycodelin A (PP14) in isolated glandular epithelial cells of normal human endometrium. Histochem. Cell Biol. 114, 405-411

Mylonas I., Winkler L., Jeschke U., Briese V. and Friese K. (2003) Untersuchungen zur Isolierung, Reinigung und Kultivierung von humanen endometrialen Zellen und zur In-vitro-Expression von Inhibin in glandulären Epithelzellen. Zentralbl. Gynakol. 125, 415-423

Raila G. (2000) Zur Pathogenese der Endometrose der Stute - Morphologisch-funktionelle Untersuchungen. Vet. Med. Diss. Universität Leipzig

Romeis B. und Böck P. (1989) Mikroskopische Technik. 17th ed. München: Urban und Schwarzenberg

Satyaswaroop P. G., Bressler R. S., de la Pena M. M. and Gurpide E. (1979) Isolation and culture of human endometrial glands. J. Clin. Endocrinol. Metab. 48, 639-641

Schoon H.-A., Schoon D. and Klug E. (1992) Uterusbiopsien als Hilfsmittel für Diagnose und Prognose von Fertilitätsstörungen der Stute. Pferdeheilkunde 8, 355-362

Schoon H.-A., Schoon D. and Klug E. (1997) Die Endometriumbiopsie bei der Stute im klinisch-gynäkologischen Kontext. Pferdeheilkunde 13, 453-464

Sheldrick E. L., Flick-Smith H. C. and Dos Santos Cruz G. J. (1993) Oxytocin receptor binding activity in cultured ovine endometrium. J. Reprod. Fertil. 98, 521-528

Shibeshi W., Abraham G., Knever C., Ellenberger C., Seeger J., Schoon H.-A. and Ungemach F. R. (2008) Isolation and culture of primary equine tracheal epithelial cells. In Vitro Cell Dev. Biol. Anim. 44, 179-184

Stief B. (2006) Heilungsvorgänge am Uterus der Stute nach minimalinvasiven chirurgischen Eingriffen. Vet. Med. Diss. Universität Leipzig

Taylor C. R., Shi S. R. and Barr N. J. (2006) Techniques of immunohistochemistry: Principles, piffalls and standardization. In: Dabbs DJ, editor. Diagnostic Immunohistochemistry. 2nd ed. Philadelphia: Elsevier Inc.; p. 1-42
Theuß T., Böttcher D., Kappe A., Schoon H.-A. and Ellenberger C. (2010) Establishment of a new method for isolation and culture of equine endometrial epithelial and stromal cells. Pferdeheilkunde, in press

Uchima F. D., Edery M., Iguchi T. and Bern H. A. (1991) Growth of mouse endometrial luminal epithelial cells in vitro: functional integrity of the oestrogen receptor system and failure of oestrogen to induce proliferation. Endocrinol. 128, 115-120

VanNiekerk C. H., Gerneke W. H. and VanHeerden J. S. (1973) Anatomical and histological observations on the reproductive tract of mares with abnormal oestrous cycles. J. South Afr. Vet. Assoc. 44, $141-152$

VanNiekerk C. H., Morgenthal J. C. and Gerneke W. H. (1975) Relationship between the morphology of and progesterone production by the corpus luteum of the mare. J. Reprod. Fertil. Suppl. 23, $171-175$

Watson E. D., Aubrey E. S., Zanecosky H. G. and Sertich P. L. (1992) Isolation and culture of glandular epithelial and stromal cells from the endometrium of mares. J. Reprod. Fertil. 95, 269-275

Yamauchi N., Yamada O., Takahashi T., Imai K., Sato T., Ito A. and Hashizume K. (2003) A Three-dimensional Cell Culture Model for Bovine Endometrium: Regeneration of a Multicellular Spheroid Using Ascorbate. Placenta 24, 258-269

Yoneda Y. (2000) Nucleocytoplasmic protein traffic and its significance to cell function. Genes Cells 5, 777-787

Zhang Y. L. and Davis D. L. (2000) Morphology of luminal and glandular epithelial cells from pig endometrium grown on plastic or extracellular matrices. J. Anim. Sci. 78, 131-138

Zhang Z., Paria B. C. and Davis D. L. (1991) Pig endometrial cells in primary culture: morphology, secretion of prostaglandins and proteins, and effects of pregnancy. J. Anim. Sci. 69, 3005-3015

Denny Böttcher

Institut für Veterinär-Pathologi

Universität Leipzig

An den Tierkliniken 33

04103 Leipzig

Germany

denny.boettcher@vetmed.uni-leipzig.de 